\title{
PENERAPAN MODEL PEMBELAJARAN \\ PROBLEM BASED LEARNING (PBL) SEBAGAI UPAYA UNTUK MENINGKATKAN KEMAMPUAN BERFIKIR KRITIS MAHASISWA TERHADAP LINGKUNGAN SEKITAR
}

\author{
Ervina Mukharomah ${ }^{1}$ Saleh Hidayat $^{2}$ \\ ${ }^{1,2}$ Program Studi Pendidikan Biologi Universitas Muhammadiyah Palembang \\ e-mail: Ervina.UMP@gmail.com
}

\begin{abstract}
This research is descriptive research, as for the purpose of this research to improve students' critical thinking ability to environmental problem by using Problem Based Learning (PBL) learning model in Environmental Science subject in Biology Education Study Program of UM Palembang. The study was conducted from September to December 2016. The results of this study indicate that PBL learning model is suitable to be applied in the subject of Environmental Knowledge. That students are able to think critically is seen from the way students solve environmental problems properly, meticulously, logically and thoroughly
\end{abstract}

\section{Keywords: Problem Based Learning (PBL), Critical Thinking, Environmental Knowledge}

\section{PENDAHULUAN}

Pembelajaran yang hanya menghabiskan waktu di dalam kelas dan dosen yang selalu aktif berbicara merupakan pembelajaran yang kurang tepat diterapkan di era gloalisasi sekarang ini. Dosen selalu berbicara di depan kelas dan mahasiswa hanya mendengarkan, hal ini membuat mahasiswa jenuh dan sulit menerima seluruh materi. Pada kasus ini mahasiwa kesulitan mengembangkan pikiran dan pendapatnya dalam menerima materi. Untuk era sekarang ini dirasa penerapan model pembelajaran yang melibatkan keaktifan mahasiswa merupakan solusi untuk pemecahan masalah ini. Oleh sebab itu dipilih model pembelajaran Problem Based Learning (PBL) yang diharapkan dengan model pembelajaran seperti ini mahasiswa memperoleh pengalaman secara langsung di lapangan sehingga mampu meningkatkan cara berpikir kritis dalam memecahan masalah.

Model pembelajaran PBL merupakan salah satu model pembelajaran yang efektif dengan melibatkan mahasiswa secara berkelompok atau individu untuk mampu memecahkan masalah yang ada disekitar dengan melakukan observasi, interview dan mencari solusi. Hal tersebut sesuai dengan pendapat Walker \& Heather (2009), Hamalik (2011) dan Pusdiklat (2004) Problem Based Learning (PBL) atau sering juga disebut dengan pembelajaran berbasis masalah dalam hal ini dosen bertindak sebagai fasilitator sehingga dapat membantu mahasiswa dalam meningkatkan pengetahuan secara teoritis dengan contoh yang autentik yang ada di lingkungan mereka. Terkait model pembelajaran yang dipilih ini cocok diterapkan pada mata kuliah yang dipilih yaitu mata kuliah Pengetahuan Lingkungan.

Pengetahuan lingkungan merupakan mata kuliah wajib yang diambil mahasiswa FKIP Biologi Semester VII Universitas Muhammadiyah Palembang. Matakuliah Pengetahuan lingkungan merupakan mata kuliah yang kaitannya erat dengan ekologi 
dan lingkungan sehingga model pembelajaran PBL cocok diterapkan pada mata kuliah ini. Mata kuliah pengetahuan lingkungan dengan penerapan model pembelajaran PBL meminta mahasiswa turun langsung ke lingkungan untuk mengamati permasalahan lingkungan dan mencarikan solusinya. Dengan demikian mahasiswa dapat meningkatkan cara berfikir kritis dalam mencari solusi untuk pemecahan masalah lingkungan, tidak hanya lingkungan kampus namun lingkungan secara umum.

Berfikir kritis dapat diartikan berfikir secara luas, beralasan sehingga dapat dipertanggung jawabkan. Hal ini sesuai dengan pendapat Hassoubah (2002) bahwa berfikir kritis merupakan cara berfikir dengan menganalisis suatu permasalahan atau gagasan untuk memperoleh ide kearah yang lebih spesifik dengan mengidentifikasi, mengkaji dan menyimpulkan gagasan secara detail ke arah sempurna.

\section{METODE PENELITIAN}

Penelitian ini termasuk ke dalam penelitian deskriptif yang tujuannya membuat deskripsi, gambar atau lukisan secara sistematis, faktual dan akurat mengenai fakta-fakta, sifat-sifat serta hubungan antar fenomena yang diteliti (Nazir, 2003). Penelitian ini dilakukan di FKIP UM Palembang, waktu penelitian dilakukan pada bulan September-Desember 2016, subjek penelitian ini adalah mahasiswa semester VII Prodi Biologi FKIP UM Palembang. Pengumpulan data dilakukan oleh peneliti dengan berinteraksi secara langsung dengan subjek penelitian sehingga peneliti dapat menegatahui pengaruh penerapan model pembelajaran PBS terhadap kemampuan berfikir kritis mahasiswa.

Langkah-langkah pembelajaran berbasis model PBL dilakukan dengan tahapan sebagai berikut:
1. Dosen memberikan penekanan tentang model pembelajaran PBL

2. Jumlah mahasiswa 33 orang dibagi menjadi 9 kelompok, pembagian kelompok ini ditentukan berdasarkan jumlah pokok bahasan yang ada

3. Masing-masing kelompok diwajibkan melakukan observasi, pendekatan, wawancara, identifikasi serta mencari pemecahan masalah-masalah lingkungan berdasarkan pokok bahasan yang ditentukan

4. Setiap minggunya satu kelompok dipersilahkan maju ke depan kelas untuk menampilkan hasil kerjanya di lapangan dengan menunjukkan makalah, Power point, serta video dan kelompok lain boleh mengomentari atau memberikan pertanyaan kepada kelompok penyaji hal tersebut bertujuan untuk melihat keberhasilan model pembelajaran PBL terhadap cara berfikir kritis mahasiswa.

Dari hasil tersebut peneliti dapat membuat pembahasan yang terangkum ke dalam abstrak sehingga dapat dibuat suatu kesimpulan dalam penelitian.

\section{HASIL DAN PEMBAHASAN}

Model pembelajaran Problem Based Learning (PBL) merupakan pembelajaran yang mengutamakan keterampilan mahasiswa dalam mengamati dan memcahkan suatu permasalahan sehingga mahasiswa memiliki cara berfikir tingkat tinggi serta memiliki rasa percaya diri terhadap pendapat yang didapat. Menurut Glazer (2001) PBL memberikan kesempatan kepada mahasiswa untuk mempelajari hal lebih luas dengan sebenarnya yang berfokus pada mempersiapkan mahasiswa untuk menjadi warga negara yang aktif dan bertanggung jawab. Menurut Hmelo-Silver \& Barrows (2006) ciri-ciri pembelajaran PBL antara lain: (a) pengajuan pertanyaan/masalah, (b) berfokus 
pada keterkaitan antar disiplin, (c) penyelidikan autentik, (d) menghasilkan produk dan memamerkannya, dan (e) kolaborasi. Dalam PBL mahasiswa dibebaskan untuk memeroleh isu-isu kunci dari masalah yang mereka hadapi, mendefinisikan kesenjangan pengetahuan mereka dan mengejar pengetahuan yang hilang sehingga mahasiswa mampu memunculkan pendapat sendiri.

Pembelajaran dengan penerapan PBL pada penelitian ini meliputi beberapa langkah yaitu 1) Persiapan yang dilakukan dosen dengan mempersiapkan Rencana Program Semester (RPS), 2) Pelaksanaan pembelajaran dengan penerapan model PBL dalam upaya mengembangkan kemampuan berpikir kritis mahasiswa; 3) Evaluasi dan Refleksi dengan subjek penelitian tentang hambatan yang ditemui dalam penerapan PBL dalam upaya mengembangkan kemampuan berpikir kritis mahasiswa di lingkungan (modifikasi Fakhriyah, 2014).

Perencanaan kegiatan pembelajaran sudah dilaksanakan oleh RPS ditulis pembelajaran yang dibuat adalah model pembelajaran PBL. Penerapan model PBL mendukung terlaksananya pembelajaran yang aktif, kreatif, efektif dan menyenangkan (PAKEM) sehingga mahasiswa akan terlibat penuh dalam proses pembelajaran, karena mahasiswa bertindak sebagai subyek pembelajaran yang sepenuhnya mahasiswa terlibat dalam proses pembelajaran. Hal ini sesuai dengan penelitian yang telah dilakukan sebelumnya oleh Fakhriyah (2014) dan Dwijanti \& Yuliani (2010) Penerapan model PBL dapat membantu menciptakan kondisi belajar yang semula hanya transfer informasi dari dosen kepada mahasiswa ke proses pembelajaran yang menekankan untuk mengkonstruksi pengetahuan berdasarkan pemahaman dan pengalaman yang diperoleh baik secara individual maupun kelompok.
Pembelajaran dengan menerapkan model PBL terlihat sangat efektif dan efesien. Hal ini terlihat dari keaktifan dan keberhasilan mahasiswa dalam memecahkan suatu permasalahan lingkungan sesuai dengan topik yang mereka bahas dengan menggunakan pemikiran yang kritis. Dapat dikatakan telah meningkatkan cara berpikir kritis karena dalam pemecahan masalah lingkungan mahasiswa terlebih dahulu melakukan observasi ke lapangan, selanjutnya melakukan pendekatan dan dilanjutkan dengan wawancara pada aparat setempat serta warga. Dari berbagai cara untuk memperoleh informasi selanjutnya mahasiswa mencari solusi untuk pemecahan masalah yang dihadapi lingkungan tersebut. Hal ini sesuai dengan pendapat Nasution, 2008 kemampuan berpikir kritis ialah mampu memecahkan maslah dengan taraf tingkat tinggi.

Hasil yang telah mahasiswa peroleh selanjutnya dibuat dalam bentuk makalah, kemudian disajikan dalam bentuk Power point dan video untuk ditayangkan di depan kelas. Terlihat kelompok lain sangat aktif dalam menanggapi dan bertanya tentang materi yang disajikan kelompok penyaji. Dari hasil diskusi kecil ini terlihat bahwa model pembelajaran PBL berhasil dilakukan pada mata kuliah pengetahuan lingkungan dengan membuat mahasiswa berpikir secara kritis. Sesuai dengan yang diungkapkan Tan (2008) bahwa dalam model pembelajaran PBL terdapat unsur berpikir kritis yang dapat dilihat dari keterampilan mengaplikasikan, menganalisa, mensintesa, mengevaluasi informasi yang diperoleh dan menggeneralisasi hasil yang diperoleh dengan tepat.

\section{SIMPULAN DAN SARAN}

Hasil dari penelitian ini menunjukkan bahwa model pembelajaran PBL cocok diterapkan pada Matakuliah Pengetahuan 
Vol. 2, No. 2 : Hal 26-29

September 2017

Lingkungan. Mahasiswa mampu berpikir kritis, hal ini terlihat dari cara mahasiswa memecahkan masalah lingkungan dengan tepat, cermat, logis dan teliti.

\section{RUJUKAN}

Dwijananti, P \& Yulianti, D. 2010. Pengembangan Kemampuan Berpikir Kritis Mahasiswa Melalui Pembelajaran Problem Based Instruction pada Mata Kuliah Fisika Lingkungan. Jurnal Pendidikan Fisikan Indonesia 692010) 108-114.

Fakhriyah, F. 2014. Penerapan Problem Based Learning untuk Mengembangkan Cara Berfikir Kritis Mahasiswa. Jurnal Pendidikan IPA Indonesia. 3 (1) (2014) 95-101.

Glazer, E. (2001). Problem based instruction. In M. Orey (Ed.), Emerging perspective on learning, teaching, and technology. Diambil di http://www.coe.uga.edu/ epltt/ProblemBasedInstruct.htm.

Hamalik, O. (2011). Proses belajar mengajar. Jakarta: Bumi Aksara.

Hassoubah, Z. I. 2002. Mengasah Pikiran Kreatif dan kritis. Jakarta: Nuansa
HmeloSilver, C. E., \& Barrows, H. S. (2006). Goals and strategies of a problembasedlearning facilitator. The interdisciplinary Journal of Problembased Learning, 1(1), 21-39

Nasution. 2008. Berbagi Pendekatan dalam Proses Belajar Mengajar.Jakarta : BumiAksara

Nazir. M. 2003. Metode Penelitian. Jakarta: Ghalian Indonesia.

Pusdiklat. (2004). Bahan Pembelajaran problem-based learning (belajar berbasis masalah). Diambil di http://www.lrckesehatan.net/cdroms_ht $\mathrm{m} / \mathrm{pbl} / \mathrm{pbl} . \mathrm{htm}$.

Tan, O.S. (2008). Problem-based learning and creativity. Singapore: Cengage Learning.

Walker, Andrew \& Heather Leary. 2009. A Problem Based Learning Meta Analysis: Differences Across Problem Types, Implementation Types, Disciplines, and Assessment Levels. The Interdisciplinary Journal of Problem-based Learning. 3 (1). 12-43 